\title{
Synthesis and Properties of Ni-doped Goethite and Ni-doped Hematite Nanorods ${ }^{\dagger}$
}

\author{
Stjepko Krehula, ${ }^{1, *}$ Mira Ristić, ${ }^{1, *}$ Ivana Mitar, ${ }^{2}$ Chuchu Wu, ${ }^{3,5}$ Xuning Li, ${ }^{3,4,6}$ Luhua Jiang, ${ }^{3,4}$ Junhu Wang, ${ }^{3,5}$ \\ Gongquan Sun, ${ }^{3}$ Tao Zhang, ${ }^{5,6}$ Marija Perović, ${ }^{7}$ Marko Bošković, ${ }^{7}$ Bratislav Antić, ${ }^{7}$ Svetozar Musić ${ }^{1,8}$
}

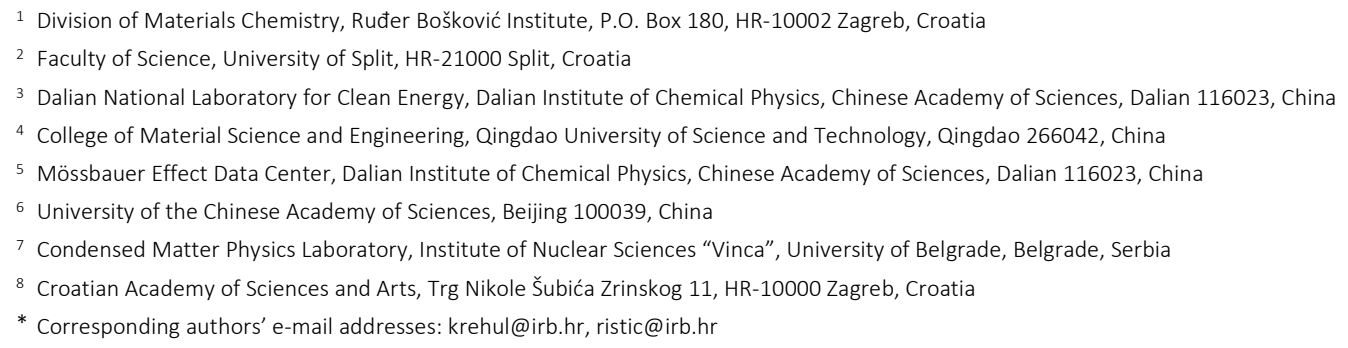

Abstract: $\mathrm{Ni}$-doped goethite $(\alpha-\mathrm{FeOOH})$ nanorods were synthesized from mixed $\mathrm{Fe}(\mathrm{III})-\mathrm{Ni}(\mathrm{II})$ nitrate solutions with various $\mathrm{Ni} /(\mathrm{Ni}+\mathrm{Fe})$ ratios $(0,5,10,20,33$ and $50 \mathrm{~mol} \% \mathrm{Ni})$ by hydrothermal precipitation in a highly alkaline medium using the strong organic alkali, tetramethylammonium hydroxide (TMAH). Ni-doped hematite $\left(\alpha-\mathrm{Fe}_{2} \mathrm{O}_{3}\right)$ nanorods were obtained by calcination of Ni-doped goethite nanorods at $400{ }^{\circ} \mathrm{C}$. The $\mathrm{Ni}^{2+}$-for-Fe ${ }^{3+}$ substitution in goethite and hematite was confirmed by determination of the unit cell expansion (due to the difference in the ionic radii of $\mathrm{Fe}^{3+}$ and $\mathrm{Ni}^{2+}$ ) using XRPD and determination of the reduction of a hyperfine magnetic field (due to the difference in magnetic moments of $\mathrm{Fe}^{3+}$ and $\mathrm{Ni}^{2+}$ ) using Mössbauer spectroscopy. Single-phase goethite nanorods were found in samples containing 0 or 5 mol \% Ni. A higher $\mathrm{Ni}$ content in the precipitation system (10 mol \% or more) resulted in a higher $\mathrm{Ni}^{2+}$-for-Fe ${ }^{3+}$ substitution in goethite, and larger $\mathrm{Ni}$ doped goethite nanorods, though with the presence of low crystalline Ni-containing ferrihydrite and $\mathrm{Ni}_{\text {ferrite }}\left(\mathrm{NiFe}_{2} \mathrm{O}_{4}\right)$ as additional phases. Significant changes in FT-IR and UV-Vis-NIR spectra of prepared samples were observed with increasing Ni content. Electrochemical measurements of samples showed a strong increase in oxygen evolution reaction (OER) electrocatalytic activity with increasing Ni content.

Keywords: $\alpha-\mathrm{FeOOH}, \alpha-\mathrm{Fe}_{2} \mathrm{O}_{3}$, Ni doping, XRPD, Mössbauer spectroscopy, FE-SEM, OER.

\section{INTRODUCTION}

D UE to their favourable properties (nontoxicity, stability, low cost, excellent absorption and adsorption properties, band gap in the visible range, etc.) iron oxides and oxyhydroxides are suitable materials for a wide range of applications (pigments, coatings, catalysts, photocatalysts, adsorbents, gas sensors, battery electrodes, etc.). ${ }^{[1-7]}$ Specific properties of iron oxides and oxyhydroxides, important for the specific application, can be tuned and improved by modifying particle size and shape, ${ }^{[8-11]}$ or by doping with various metal cations. ${ }^{[12-15]}$

Goethite $(\alpha-\mathrm{FeOOH})$ is the most stable iron oxyhydroxide that can incorporate various metal (M) cations into its crystal structure (Figure 1a) by substitution for $\mathrm{Fe}^{3+}$ ions at octahedral sites. ${ }^{[1]}$ The M-for-Fe substitution can significantly change the properties of goethite. $\mathrm{Ni}$ doped goethite (with up to $4 \mathrm{~mol} \mathrm{\%} \mathrm{Ni}$ ) is a major component of nickel laterite ores (the most important source of nickel). ${ }^{[16-19]}$ Incorporation of $\mathrm{Ni}$ in synthetic goethite has been reported in several publications. ${ }^{[20-24]}$ $\mathrm{Ni}^{2+}-$ for-Fe $\mathrm{Fe}^{3+}$ substitution in goethite was confirmed by determination of a slight increase in unit cell volume due the different ionic radii of $\mathrm{Ni}^{2+}(0.69 \AA)$ and $\mathrm{Fe}^{3+}(0.645 \AA)$. [25] Substitution increases with increased $\mathrm{Ni}$ content in the initial precursor and is higher in the surface layer of $\mathrm{Ni}$ doped goethite particles than in the inner layers. ${ }^{[21,22]} \mathrm{Ni}$ doping in goethite causes a decrease in the hyperfine

This work is licensed under a Creative Commons Attribution 4.0 International License.

+ This paper was presented at the $4^{\text {th }}$ Mediterranean Conference on the Applications of the Mössbauer Effect (MECAME 2018), 
magnetic field, ${ }^{[23]}$ an increase in dehydroxylation temperature, ${ }^{[24]}$ an increase in the adsorption of arsenate ${ }^{[26]}$ or chromate ${ }^{[27]}$ ions, and an increase in goethite catalytic activity as a heterogeneous Fenton catalyst. [28]

Hematite $\left(\alpha-\mathrm{Fe}_{2} \mathrm{O}_{3}\right)$ is the most stable of the iron(III) oxide polymorphs. Substitution of different metal cations for $\mathrm{Fe}^{3+}$ ions in the crystal structure of hematite (Figure $1 \mathrm{~b}$ ) has been reported in a number of papers, ${ }^{[1,29-39]}$ listing significant changes in the different properties of hematite following $\mathrm{M}$-for-Fe substitution. Ni doping in hematite has been investigated by several research groups. Singh et al. ${ }^{[40]}$ prepared $\mathrm{Ni}$-doped hematite by aging $\mathrm{Fe}-\mathrm{Ni}$ hydroxide gel at $\mathrm{pH} 7.5-8.0$ and $90{ }^{\circ} \mathrm{C}$ for 14 days. The substitution of up to $6 \mathrm{~mol} \% \mathrm{Ni}$ in the hematite structure, accompanied by an expansion of the unit cell was reported. IR spectroscopy showed that $\mathrm{Ni}^{2+}$-for- $-\mathrm{Fe}^{3+}$ substitution in hematite is also accompanied by a corresponding $\mathrm{OH}^{-}$for $\mathrm{O}^{2-}$ substitution in order to maintain the charge balance. ${ }^{[40]}$ Increased magnetic susceptibility and remanent magnetization by $\mathrm{Ni}$-for-Fe substitution in hematite were observed. ${ }^{[41]} \mathrm{Ni}$-doped hematite prepared by calcination of metal oxinates ${ }^{[42]}$ showed decreased unit cell compared to undoped hematite, which was explained by the presence of oxygen and structural vacancy sites. Liu et al. ${ }^{[43]}$ reported increased conductivity, reduced indirect and direct band gap energies and enhanced photoelectrocatalytic activity of electrodeposited hematite thin films by Ni doping.

lervolino et al. ${ }^{[4]}$ also observed a reduced band gap and enhanced photoelectrocatalytic activity of electrodeposited hematite thin films by $\mathrm{Ni}$ doping. Zhao and Koe ${ }^{[45]}$ prepared a Ni-doped hematite (0001) surface and conducted electrochemical measurements to determine a higher current density and a lower onset potential for OER compared to undoped hematite. Kocher et al. ${ }^{[46]}$ reported an expanded unit cell and decreased direct and indirect band gap energies of hematite by $\mathrm{Ni}$ doping. Lemine et al. ${ }^{[47]}$ also observed unit cell expansion in nanocrystalline $\mathrm{Ni}$-doped hematite samples prepared by high-energy ballmilling of $\mathrm{Ni}$ metal and $\alpha-\mathrm{Fe}_{2} \mathrm{O}_{3}$. Nanocrystalline Ni-doped hematite has been found to be a highly efficient sorbent for Cd, Co and Ni from aqueous solution. ${ }^{[47]}$ Satheesh et al. ${ }^{[48]}$ prepared metal-doped hematites by calcination of mixed hydroxides and reported lower visible light photocatalytic activity of Ni-doped hematite compared to Cu-doped, Codoped and undoped hematite. Reduced visible light photocatalytic activity of Ni-doped hematite compared to undoped hematite was also reported by de Melo et al. ${ }^{[49]}$ Lassoued et al. ${ }^{[50]}$ reported hematite band gap lowering and increased visible light photocatalytic activity by $\mathrm{Ni}$ doping. Sivakumar et al. ${ }^{[51]}$ observed a larger unit cell, reduced band gap energies, decreased coercivity and increased saturation magnetization of hematite by $\mathrm{Ni}$ doping. Wang et al. ${ }^{[52]}$ prepared pom-pom-like Ni-doped $\alpha$ -
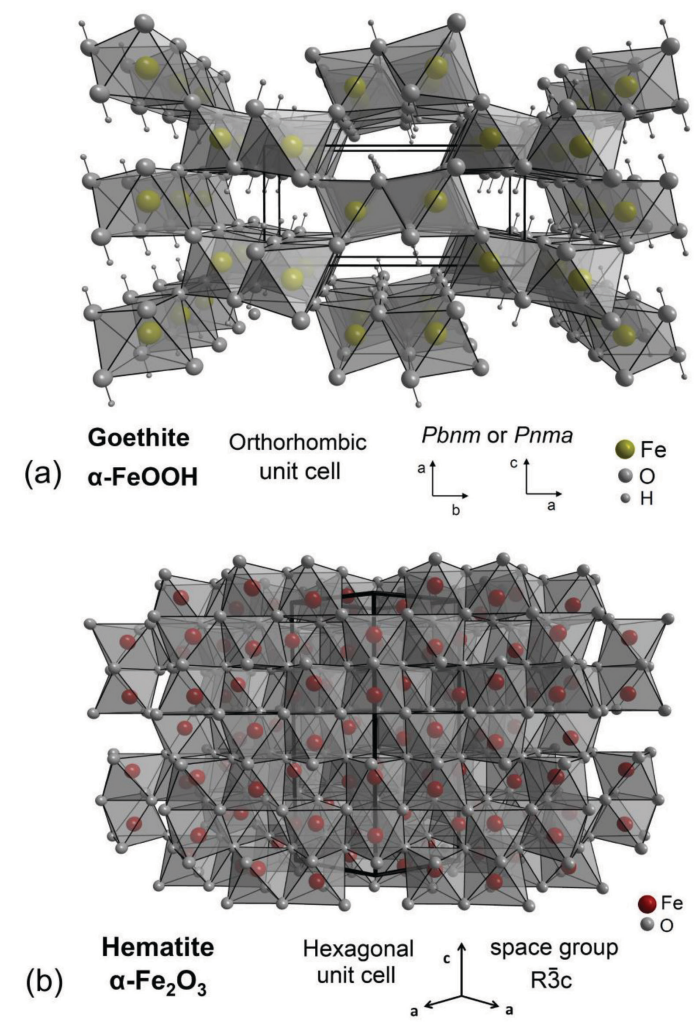

Figure 1. Crystal structures of (a) goethite $(\alpha-\mathrm{FeOOH})$ and (b) hematite $\left(\alpha-\mathrm{Fe}_{2} \mathrm{O}_{3}\right)$ phases represented by the cation polyhedra. The space group, crystallographic axes and unit cell are designated.

$\mathrm{Fe}_{2} \mathrm{O}_{3}$ nanostructures by calcination of $\mathrm{Ni}$-doped $\alpha-\mathrm{FeOOH}$ nanostructures of the same shape. They reported high adsorption performance of $\mathrm{Ni}$-doped $\alpha-\mathrm{Fe}_{2} \mathrm{O}_{3}$ nanostructures in removing Congo red (CR) dye from water. Cheng et al. ${ }^{[53]}$ reported a highly active photoanode consisting of a thin Ni-doped hematite overlayer on the surface of hematite nanotubes. The presence of $\mathrm{Ni}$ in overlayer hematite promotes the charge migration of photogenerated carriers to the surface, thus accelerating surface oxygen evolution and avoiding low-energy, photoexcited holes recombination at the semiconductor-liquid junction. ${ }^{[53]}$ Suresh et al. ${ }^{[54]}$ used Ni-doped hematite nanoparticles to fabricate an electrochemical sensor for the detection of uric acid (UA) in biological conditions by cyclic voltammetry (CV) and chronoamperometry (CA).

This literature review outlines the different approaches in the synthesis of $\mathrm{Ni}$-doped goethites and $\mathrm{Ni}$ doped hematites, and differences in the properties of these materials with regard to the synthesis method. The aim of the present study was to obtain more accurate data about the structural, microstructural and other properties of $\mathrm{Ni}$ doped goethites and Ni-doped hematites. Ni-doped goethites were prepared by a coprecipitation method using 
the very strong organic alkali, tetramethylammonium hydroxide as a precipitating agent. This synthesis method produced goethite nanorods of better uniformity compared to other methods where $\mathrm{NaOH}$ or $\mathrm{KOH}$ were used. ${ }^{[55,56]} \mathrm{Ni}$-doped hematites were obtained by calcination of $\mathrm{Ni}$-doped goethites at $400^{\circ} \mathrm{C}$.

\section{EXPERIMENTAL}

Iron(III) nitrate nonahydrate, $\mathrm{Fe}\left(\mathrm{NO}_{3}\right)_{3} \cdot 9 \mathrm{H}_{2} \mathrm{O}$, of analytical purity, supplied by Kemika, nickel(II) nitrate hexahydrate, $\mathrm{Ni}\left(\mathrm{NO}_{3}\right)_{2} \cdot 6 \mathrm{H}_{2} \mathrm{O}$, of analytical purity, supplied by Kemika and a tetramethylammonium hydroxide (TMAH) solution, $\left(\mathrm{CH}_{3}\right)_{4} \mathrm{NOH}, 25 \% \mathrm{w} / \mathrm{w}$, electronic grade $99.9999 \%$, supplied by Alfa Aesar ${ }^{\circledR}$, were used. Concentrated aqueous solutions of $\mathrm{Fe}(\mathrm{III})$ and $\mathrm{Ni}(\mathrm{II})$ nitrates were prepared. Mixed $\mathrm{Fe}(\mathrm{III})$ $\mathrm{Ni}(\mathrm{II})$ nitrate solutions of varying ratios $(0,5,10,20,33$ and $50 \mathrm{~mol} \% \mathrm{Ni}$ ) were used as shown in Table 1. TMAH was added in surplus ( $\mathrm{pH}$ about 13.5) to the obtained mixed $\mathrm{Fe}(\mathrm{III})-\mathrm{Ni}(\mathrm{II})$ nitrate solutions. The overall concentration of metal cations $\left(\mathrm{Fe}^{3+}+\mathrm{Ni}^{2+}\right)$ in the precipitation system was $0.1 \mathrm{~mol} \mathrm{dm}^{-3}$. The aqueous suspensions $(80 \mathrm{ml})$ were shaken vigorously for about 5 minutes, then hydrothermally treated at $160^{\circ} \mathrm{C}$ for 2 hours using the Parr generalpurpose acid digestion bomb (model 4748, $125 \mathrm{ml}$ ) comprising a Teflon vessel and a cup. After hydrothermal treatment, precipitates were cooled to room temperature and subsequently washed with twice-distilled water to remove "neutral electrolytes". An ultraspeed LaboGene $2236 R$ centrifuge was used. Washed samples were vacuum dried overnight. The obtained powder samples were named after their $\mathrm{Ni}$ content in $\mathrm{mol} \%$, from $\mathrm{NiO}$ to $\mathrm{Ni} 50$. The samples $\mathrm{NiO}-400$ to $\mathrm{Ni50}-400$ were prepared by calcination of the samples $\mathrm{NiO}$ to $\mathrm{Ni} 50$ at $400^{\circ} \mathrm{C}$ for 2 hours (Table 1). Approximately the same $\mathrm{Ni}$ to Fe ratio as in the initial mixed solutions was estimated in prepared powder samples using EDS.

An X-ray powder diffractometer APD 2000 (CUKa radiation, graphite monochromator, Nal-TI detector) manufactured by ItalStructures (G.N.R. s.r.I., Novara, Italy) was used. Potassium bromide (Sigma-Aldrich, > $99 \%$ trace metals basis) was used as an internal standard. The Rietveld refinements of XRD data were performed using the MAUD program..$^{[57]}$

A JEOL thermal field emission scanning electron microscope (FE-SEM, model JSM-7000F) was used to observe particle morphology. The FE-SEM was linked to an Oxford Instruments EDS/INCA 350 energy dispersive X-ray analyser for elemental analysis. Specimens were not coated with an electrically conductive surface layer.

The ${ }^{57} \mathrm{Fe}$ Mössbauer spectra were recorded at $20^{\circ} \mathrm{C}$ (293 K) in transmission mode using a standard WissEl (Starnberg, Germany) instrumental configuration. $\mathrm{A}^{57} \mathrm{Co} / \mathrm{Rh}$ Mössbauer source was used. The velocity scale and all data refer to the metallic $\alpha$-Fe absorber at $20^{\circ} \mathrm{C}$. A quantitative analysis of the recorded spectra was made using the MossWinn program. ${ }^{[58]}$

Magnetic measurements were carried out on a superconducting quantum interference device (SQUID) magnetometer (Quantum Design MPMS XL-5).

Fourier transform infrared (FT-IR) spectra were recorded at RT in ATR mode using a Tensor II spectrometer (Bruker).

Table 1. Ni and Fe content in initial mixed solutions and phase composition of prepared powder samples as determined by X-ray powder diffraction. $(\mathrm{Ni}, \mathrm{Fe})(\mathrm{OH})_{2}$ phase contains both $\beta-\mathrm{Ni}(\mathrm{OH})_{2}$ and $\alpha-\mathrm{Ni}(\mathrm{OH})_{2}$ structural units.

\begin{tabular}{|c|c|c|c|}
\hline Sample & $\mathrm{Ni} / \mathrm{mol} \%$ & $\mathrm{Fe} / \mathrm{mol} \%$ & Phase composition by XRD \\
\hline $\mathrm{NiO}$ & 0 & 100 & $\alpha-\mathrm{FeOOH}$ \\
\hline $\mathrm{Ni} 5$ & 5 & 95 & $\alpha-(\mathrm{Fe}, \mathrm{Ni}) \mathrm{OOH}$ \\
\hline Ni10 & 10 & 90 & $\alpha-(\mathrm{Fe}, \mathrm{Ni}) \mathrm{OOH}+\mathrm{Ni}$-ferrihydite $+\mathrm{NiFe}_{2} \mathrm{O}_{4}$ \\
\hline $\mathrm{Ni20}$ & 20 & 80 & $\alpha-(\mathrm{Fe}, \mathrm{Ni}) \mathrm{OOH}+\mathrm{Ni}$-ferrihydite $+\mathrm{NiFe}_{2} \mathrm{O}_{4}$ \\
\hline $\mathrm{Ni33}$ & 33 & 67 & $\alpha-(\mathrm{Fe}, \mathrm{Ni}) \mathrm{OOH}+\mathrm{Ni}$-ferrihydite $+\mathrm{NiFe}_{2} \mathrm{O}_{4}$ \\
\hline $\mathrm{Ni50}$ & 50 & 50 & $\alpha-(\mathrm{Fe}, \mathrm{Ni}) \mathrm{OOH}+\mathrm{Ni}$-ferrihydite $+\mathrm{NiFe}_{2} \mathrm{O}_{4}+(\mathrm{Ni}, \mathrm{Fe})(\mathrm{OH})_{2}$ \\
\hline $\mathrm{NiO}-400$ & 0 & 100 & $\alpha-\mathrm{Fe}_{2} \mathrm{O}_{3}$ \\
\hline $\mathrm{Ni5}-400$ & 5 & 95 & $\alpha-(\mathrm{Fe}, \mathrm{Ni})_{2} \mathrm{O}_{3}$ \\
\hline Ni10-400 & 10 & 90 & $\alpha-(\mathrm{Fe}, \mathrm{Ni})_{2} \mathrm{O}_{3}+\mathrm{NiFe}_{2} \mathrm{O}_{4}$ \\
\hline $\mathrm{Ni} 20-400$ & 20 & 80 & $\alpha-(\mathrm{Fe}, \mathrm{Ni})_{2} \mathrm{O}_{3}+\mathrm{NiFe}_{2} \mathrm{O}_{4}$ \\
\hline Ni33-400 & 33 & 67 & $\alpha-(\mathrm{Fe}, \mathrm{Ni})_{2} \mathrm{O}_{3}+\mathrm{NiFe}_{2} \mathrm{O}_{4}+(\mathrm{Ni}, \mathrm{Fe}) \mathrm{O}$ \\
\hline $\mathrm{Ni50}-400$ & 50 & 50 & $\alpha-(\mathrm{Fe}, \mathrm{Ni})_{2} \mathrm{O}_{3}+\mathrm{NiFe}_{2} \mathrm{O}_{4}+(\mathrm{Ni}, \mathrm{Fe}) \mathrm{O}$ \\
\hline
\end{tabular}


Diffuse reflectance UV-Vis-NIR spectra were obtained at $20{ }^{\circ} \mathrm{C}$ using a Shimadzu UV-Vis-NIR spectrometer (model UV-3600) equipped with an integrated sphere. Barium sulfate was used as reference.

Selected samples were evaluated electrochemically in a three-electrode, one-compartment cell using a $\mathrm{Hg} / \mathrm{HgO}$ electrode $(0.1 \mathrm{M} \mathrm{NaOH})$ and a Pt wire as the reference and counter electrode, respectively. To prepare the working electrode, $3.5 \mathrm{mg}$ catalyst powder and $1.5 \mathrm{mg}$ carbon powder (Vulcan XC72) with $30 \mu \mathrm{L}$ Nafion (sulfonated tetrafluorethylene based fluoropolymer-copolymer) solution (5 wt \%) were ultrasonically dispersed in $2 \mathrm{~mL}$ ethanol solvent to form a homogeneous ink. The catalyst loading was $\sim 0.1786 \mathrm{mg} \mathrm{cm}^{-2}$. The electrolyte comprised $0.1 \mathrm{M}$ $\mathrm{NaOH}$ aqueous solution saturated with high-purity $\mathrm{O}_{2}$. Voltammetric tests were carried out at room temperature using a computer-controlled $\mathrm{CHI} 760 \mathrm{~B}$. The electrode was scanned at a rate of $10 \mathrm{mV} \mathrm{s}^{-1}$.

\section{RESULTS AND DISCUSSION}

The XRPD patterns of the samples $\mathrm{NiO}$ to Ni50 are shown in Figure 2, along with the positions and intensities of diffraction lines of goethite $(\alpha-\mathrm{FeOOH})$ given in the ICDD PDF card No. 29-0713. Diffraction lines characteristic of goethite are present in all patterns in Figure 2, confirming goethite as the dominant phase in these samples. XRPD patterns of the samples with $10 \mathrm{~mol} \% \mathrm{Ni}$ or higher indicate the presence of small amounts of $\mathrm{Ni}$ ferrite $\left(\mathrm{NiFe}_{2} \mathrm{O}_{4}, \mathrm{ICDD}\right.$ PDF card No. 54-0964) as an additional phase in these samples. The presence of $\mathrm{Ni}$ ferrite in these samples was also confirmed by magnetic measurements at $300 \mathrm{~K}$ (Figure 3 ), which showed the presence of the narrow hysteresis loop characteristic for $\mathrm{Ni}$ ferrite nanoparticles. ${ }^{[59]}$ The presence of a small amount of $(\mathrm{Ni}, \mathrm{Fe})(\mathrm{OH})_{2}$ phase is visible in the XRPD pattern of the Ni50 sample. Also, the increased background in XRPD patterns in Figure 2 with increasing $\mathrm{Ni}$ content indicates the presence of a significant amount of a low crystalline (Ni-ferrihydrite) and/or amorphous $\mathrm{Fe}-\mathrm{Ni}$ hydroxide phase.

Goethite diffraction lines are slightly shifted to lower $2 \theta$ values with increased $\mathrm{Ni}$ content, indicating a small expansion of the unit cell due to $\mathrm{Ni}$-for-Fe substitution in the crystal structure of goethite. Unit cell parameters and volume, calculated using Rietveld refinement of XRPD patterns, are given in Table 2. Due to the small difference in the ionic radius of $\mathrm{Fe}^{3+}(0.645 \AA)$ and $\mathrm{Ni}^{2+}(0.69 \AA)$ ions ${ }^{[25]}$ the unit cell of goethite was only slightly expanded by the $\mathrm{Ni}$-for-Fe substitution. In line with previous studies, ${ }^{[20,21,24]}$ unit cell expansion was most significant along the $b$-axis direction. This non-uniform expansion of the unit cell was most likely caused by a different distortion of the

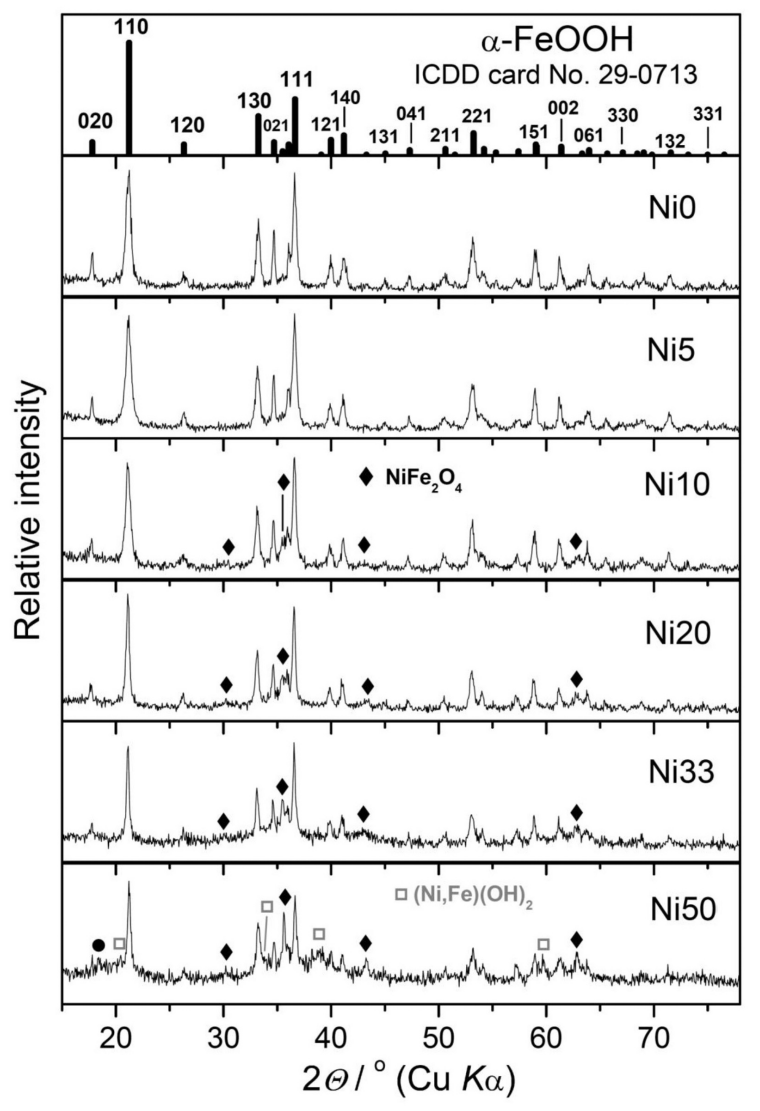

Figure 2. XRD powder patterns of prepared Ni-doped goethite samples. Positions and intensities of $\alpha-\mathrm{FeOOH}$ diffraction lines as given in the Powder Diffraction File (PDF) of the International Centre for Diffraction Data (ICDD) are also shown.

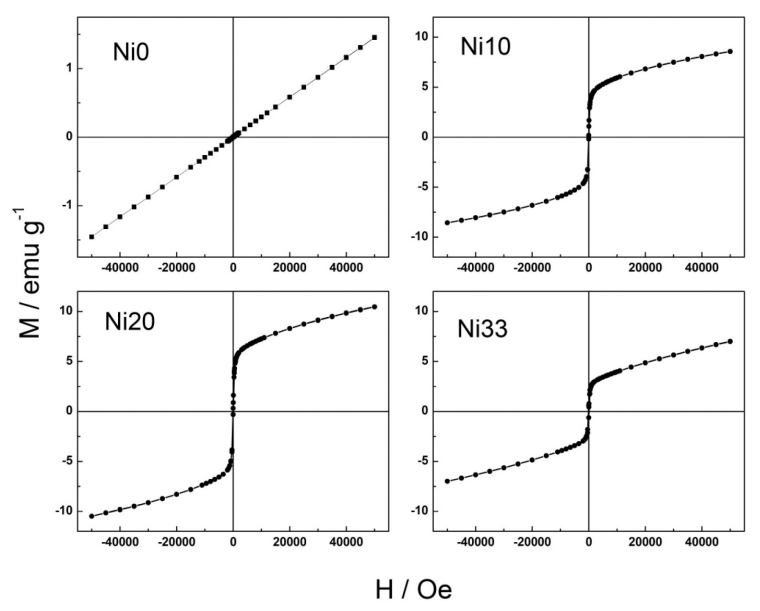

Figure 3. Magnetic field dependence of magnetization for selected $\mathrm{Ni}$-doped goethite samples measured at $300 \mathrm{~K}$. 
Table 2. Unit-cell parameters, FWHM values of the strongest line in the XRD patterns and average crystallite size of Ni-doped goethite samples

\begin{tabular}{|c|c|c|c|c|c|c|c|}
\hline \multirow{2}{*}{ Sample } & \multirow{2}{*}{$\mathrm{Ni} / \mathrm{mol} \%$} & \multicolumn{3}{|c|}{ Unit cell parameter / ^̊ } & \multirow{2}{*}{$V / \AA^{3}$} & \multirow{2}{*}{$\begin{array}{c}\text { FWHM (110) / } \\
{ }^{\circ} 2 \Theta\end{array}$} & \multirow{2}{*}{$d_{110} / \mathrm{nm}$} \\
\hline & & $a$ & $b$ & c & & & \\
\hline$G^{(a)}$ & 0.0 & 4.608 & 9.956 & 3.0215 & 138.6 & - & - \\
\hline $\mathrm{NiO}$ & 0.0 & $4.618(1)$ & $9.956(2)$ & $3.024(1)$ & 139.03(9) & $0.56(1)$ & $16(1)$ \\
\hline $\mathrm{Ni} 5$ & 5.0 & $4.618(1)$ & $9.970(1)$ & $3.024(0)$ & $139.23(5)$ & $0.56(1)$ & $16(1)$ \\
\hline Ni10 & 10.0 & $4.620(1)$ & $9.973(2)$ & $3.025(1)$ & $139.35(9)$ & $0.48(2)$ & $19(1)$ \\
\hline $\mathrm{Ni} 20$ & 20.0 & $4.619(1)$ & $9.980(1)$ & $3.025(0)$ & $139.45(6)$ & $0.31(1)$ & $33(1)$ \\
\hline $\mathrm{Ni33}$ & 33.3 & $4.619(1)$ & $9.978(2)$ & $3.026(1)$ & $139.46(9)$ & $0.27(1)$ & $39(2)$ \\
\hline
\end{tabular}

(a) standard goethite (ICDD card No. 29-0713)

octahedral site occupied by $\mathrm{Ni}^{2+}$ compared to the octahedral site occupied by $\mathrm{Fe}^{3+}$ due to the difference in electron configurations of these two cations $\left(3 d^{8}\right.$ and $3 d^{5}$, respectively). The different charges of $\mathrm{Ni}^{2+}$ and $\mathrm{Fe}^{3+}$ could also affect the non-uniform unit cell expansion with substitution of $\mathrm{FeO}_{3}(\mathrm{OH})_{3}$ octahedra by $\mathrm{NiO}_{2}(\mathrm{OH})_{4}$ octahedra of a different distortion. ${ }^{[18,60]}$

A higher $\mathrm{Ni}$ content in the precipitation system resulted in higher $\mathrm{Ni}$-for-Fe substitution in goethite, in line with previous studies. ${ }^{[20,22,24]} \mathrm{Ni}$ present in the precipitation system was only partially incorporated into goethite due to the incongruent release of $\mathrm{Ni}$ from the amorphous $\mathrm{Fe}-\mathrm{Ni}$ hydroxide (Ni-ferrihydrite) initially formed in the system. ${ }^{[22]}$ By comparison with data reported by Gerth ${ }^{[20]}$ (the size of goethite unit cell for different amounts of incorporated $\mathrm{Ni}$ ), the $\mathrm{Ni}$ content in goethite was estimated to about $3 \mathrm{~mol} \%$ in sample $\mathrm{Ni} 5,4 \mathrm{~mol} \%$ in sample Ni10 and 5 to $6 \mathrm{~mol} \%$ in samples $\mathrm{Ni2O}$ and $\mathrm{Ni33}$. The remainder of the $\mathrm{Ni}$ occurred as $\mathrm{Ni}$ ferrite formed from the residual and less soluble $\mathrm{Ni}$ rich ferrihydrite following prolonged hydrothermal treatment. The average size of the $\mathrm{Ni}$-doped goethite crystallites, estimated from the full width at half maximum (FWHM) of the (110) diffraction line using the Scherrer equation, is also given in Table 2. Larger $\mathrm{Ni}$-doped goethite crystallites were formed at a higher $\mathrm{Ni}$ content in the precipitation system, which is likely associated with the increased stability of intermediate $\mathrm{Ni}$-doped ferrihydrite during goethite formation by the dissolution-precipitation mechanism. An increase in size of metal-doped goethite crystallites and particles, formed by the same mechanism, was also observed in the case of $\mathrm{Mn}$, Ir or In doping of goethite. ${ }^{[61-64]}$

The XRPD patterns of the calcined samples NiO-400 to Ni50-400 are shown in Figure 4 along with the positions and intensities of diffraction lines of the standard hematite $\left(\alpha-\mathrm{Fe}_{2} \mathrm{O}_{3}\right), \mathrm{ICDD}$ PDF card No. 33-0664. Diffraction lines characteristic of hematite are present in all patterns in Figure 4, confirming hematite as the dominant phase in these samples. Ni ferrite diffraction lines of low intensity are also present in the patterns of samples with $10 \mathrm{~mol} \%$ $\mathrm{Ni}$ or higher, while broad diffraction lines of $\mathrm{NiO}$ (ICDD PDF card No. 47-1049), likely containing incorporated $\mathrm{Fe}$, are present in the patterns of samples containing 33 and 50 $\mathrm{mol} \% \mathrm{Ni}$

The widths of the strongest hematite diffraction lines (104) and (110) (as well as the widths of other, less intense lines) differ significantly, which is typical for hematite prepared by calcination of goethite nanorods at temperatures $<500{ }^{\circ} \mathrm{C}$. ${ }^{65]}$ This phenomenon was explained by the presence of two different iron stacking sequences

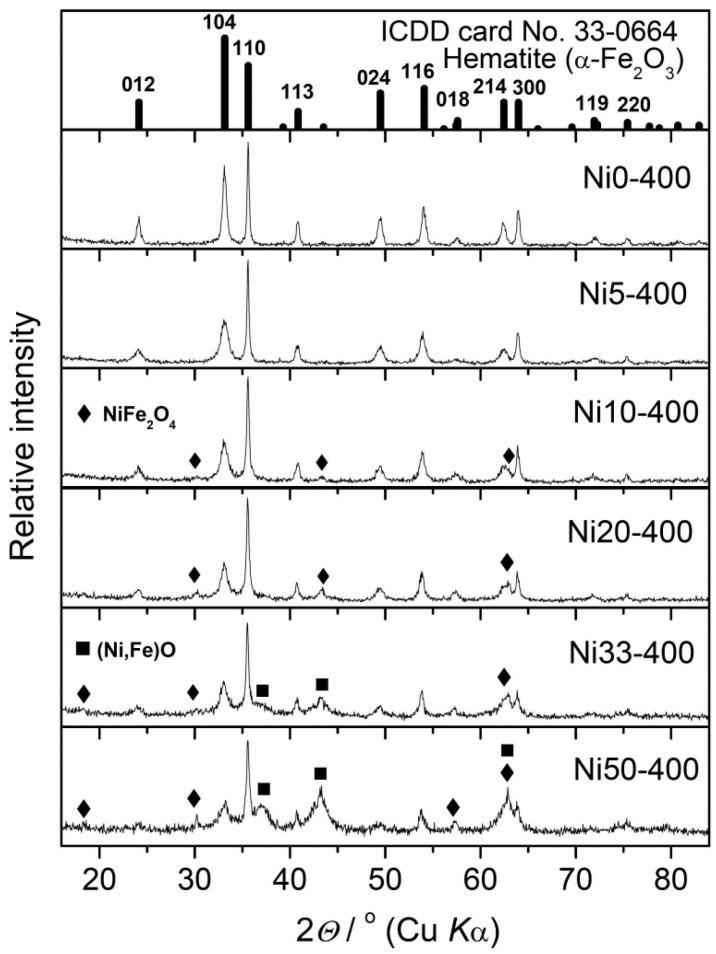

Figure 4. XRD powder patterns of Ni-doped hematite samples. Positions and intensities of $\alpha-\mathrm{Fe}_{2} \mathrm{O}_{3}$ diffraction lines as given in the Powder Diffraction File (PDF) of the International Centre for Diffraction Data (ICDD) are also shown. 
Table 3. Unit cell parameters and FWHM values of strongest diffraction lines of $\mathrm{Ni}$-doped hematite samples

\begin{tabular}{|c|c|c|c|c|c|c|}
\hline \multirow{2}{*}{ Sample } & \multirow{2}{*}{$\mathrm{Ni} / \mathrm{mol} \%$} & \multicolumn{2}{|c|}{ Unit cell parameter / $\AA$} & \multirow{2}{*}{$V / \AA^{3}$} & \multicolumn{2}{|c|}{ FWHM (110) / ${ }^{\circ} 2 \theta$} \\
\hline & & $a$ & c & & (104) & (110) \\
\hline$H^{(a)}$ & 0.0 & 5.0356 & 13.7489 & 301.9 & - & - \\
\hline $\mathrm{NiO}-400$ & 0.0 & $5.0365(4)$ & $13.754(2)$ & $302.1(1)$ & $0.469(13)$ & $0.176(14)$ \\
\hline $\mathrm{Ni5}-400$ & 5.0 & $5.0379(7)$ & $13.767(3)$ & $302.6(1)$ & $0.835(27)$ & $0.184(26)$ \\
\hline $\mathrm{Ni} 10-400$ & 10.0 & $5.0382(4)$ & $13.770(4)$ & $302.7(1)$ & $0.780(35)$ & $0.212(25)$ \\
\hline $\mathrm{Ni} 2 \mathrm{O}-400$ & 20.0 & $5.0393(6)$ & $13.768(5)$ & $302.8(1)$ & $0.733(46)$ & $0.281(14)$ \\
\hline $\mathrm{Ni33}-400$ & 33.3 & $5.0391(8)$ & $13.771(2)$ & $302.8(2)$ & $0.758(57)$ & $0.233(27)$ \\
\hline
\end{tabular}

(a) standard hematite (ICDD card No. 33-0664)

(twin orientations) in the same hexagonal close-packed oxygen framework of hematite obtained by calcination of goethite. ${ }^{665,66]}$ Very small twin domains in hematite prepared by calcination of goethite nanorods at temperatures $<500{ }^{\circ} \mathrm{C}$ affect broadening of diffraction lines (012), (104), (018), (024) and (214), which are dominated by scattering at the iron sub-lattice. Diffraction lines which contain contributions from oxygen sub-lattice, (110), (113), (116) and (300), are much narrower. ${ }^{[65]}$ Diffraction patterns of Ni-doped hematite samples (Figure 4) show an increase in width of diffraction line (104) and widths of other lines dominated by scattering at the iron sub-lattice with increased $\mathrm{Ni}$ content due to increased cation stacking disorder and smaller twin domains. Also, the relative intensities of these lines relative to oxygen sub-lattice dominated lines are lower compared to diffraction pattern of standard hematite sample and decrease with increased Ni doping in hematite. This observation can be explained by the presence of iron-deficient, $\mathrm{OH}$-containing hematite-like phase ("protohematite") ${ }^{[67]}$ in samples obtained by calcination of goethite and Ni-doped goethite at $400{ }^{\circ} \mathrm{C}$. Ni doping affected a decrease in relative intensity of iron sublattice lines due to an increase in iron deficiency. A decreased relative intensity of diffraction lines related to the iron sub-lattice has been reported for hematite prepared by calcination of goethite doped with various metal cations. ${ }^{[24]}$ As in the case of goethite, hematite diffraction lines are slightly shifted to lower $2 \theta$ values with increased Ni content, due to a small expansion of the unit cell by $\mathrm{Ni}^{2+}-$ for- $\mathrm{Fe}^{3+}$ substitution in the structure of hematite. Unit cell parameters and volume (determined using Rietveld refinement of XRPD patterns), and FWHM values are given in Table 3.

FE-SEM images of undoped goethite (sample $\mathrm{NiO}$ ) and $\mathrm{Ni}$-doped goethite samples ( $\mathrm{Ni5}, \mathrm{Ni10}, \mathrm{Ni} 20, \mathrm{Ni33}$ and Ni50) are shown in Figure 5. Characteristic goethite nanorods with an average length, width and thickness of about 200, 50 and $20 \mathrm{~nm}$, respectively, are present in sample NiO. Smaller goethite nanorods, formed in the presence of $5 \mathrm{~mol} \% \mathrm{Ni}$, are visible in the FE-SEM image of sample Ni5. However, with a further increase in Ni content, there is a significant increase in the size of the goethite nanorods. In line with XRPD results, which revealed an increase in goethite crystallite size by Ni doping, increasing size of the goethite nanorods by Ni doping (SEM images of samples Ni20, Ni33 and Ni50) was also evident, similar to the doping of goethite with $\mathrm{Mn}$, Ir or In.$^{[61-64]}$ In the images of samples with high $\mathrm{Ni}$ content, both $\mathrm{Ni}$ ferrite nanoparticles and elongated goethite particles are present. FE-SEM images of calcined samples (Figure 6) showed the presence of $\mathrm{Ni}$-doped hematite nanorods and nanoparticles of minor phases with unchanged size and shape compared to the initial samples prior to calcination.

The ${ }^{57} \mathrm{Fe}$ Mössbauer spectra of goethite and $\mathrm{Ni}$ doped goethite samples are shown in Figure 7 (left). The calculated Mössbauer parameters and phase identification
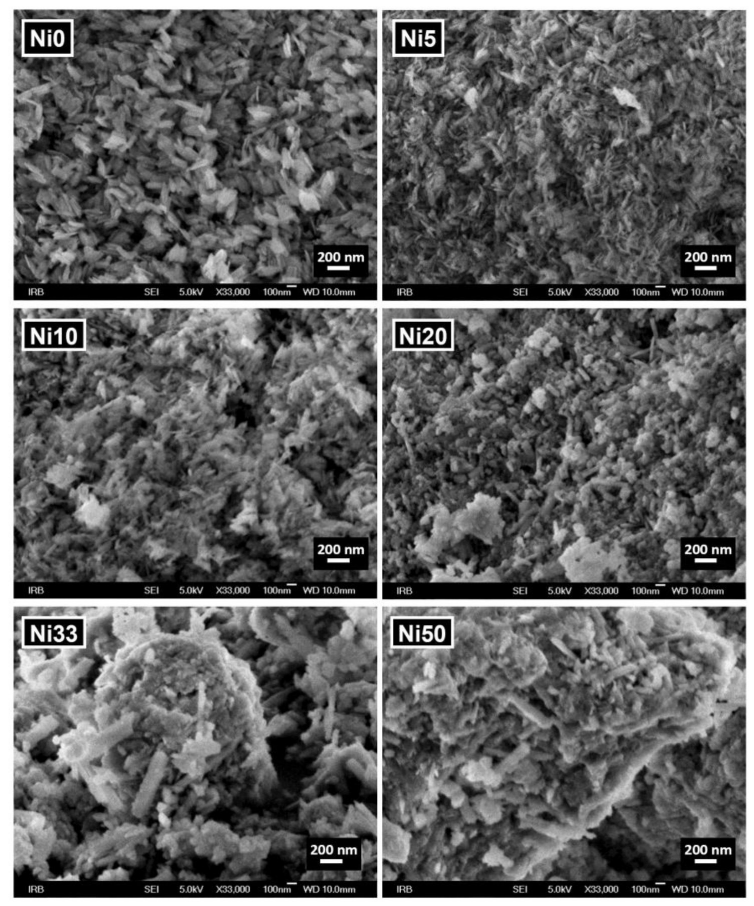

Figure 5. FE-SEM images of Ni-doped goethite samples. 

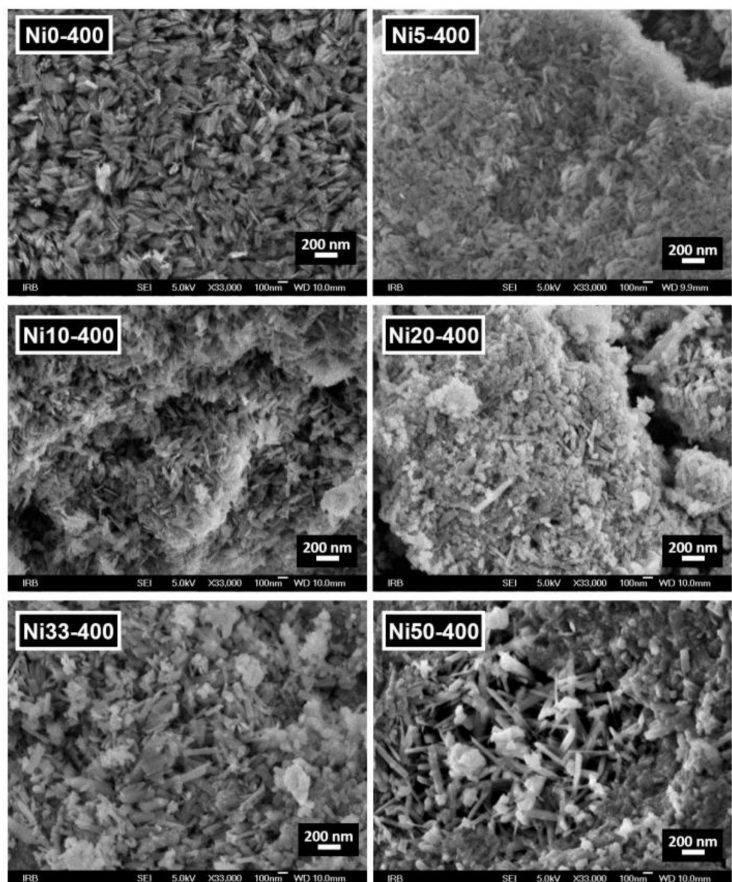

Figure 6. FE-SEM images of Ni-doped hematite samples.

are given in Table 4. All the spectra contain a sextet with Mössbauer parameters characteristic of goethite as the major component. The spectra of goethite and Ni-doped goethite were fitted by taking the hyperfine magnetic field (HMF) distribution into account. These HMF distributions along with their average values are given in Figure 7 (right). HMF distributions are broadened by Ni doping because of the reduction of HMF at some Fe nuclei due to the Ni-forFe substitution in their vicinity. The magnetic moment of $\mathrm{Ni}^{2+}$ ions with two unpaired electron spins is significantly lower than the magnetic moment of $\mathrm{Fe}^{3+}$ ions with five unpaired electron spins, which strongly affects HMF at the nearby $\mathrm{Fe}$ nuclei due to the reduced superexchange interaction. A quadrupole doublet, which increases in intensity with increasing $\mathrm{Ni}$ content, can be attributed to $\mathrm{Fe}^{3+}$ ions in the low-crystalline or amorphous phase ( $\mathrm{Ni}-\mathrm{Fe}$ hydroxide or low crystalline Ni-ferrite or Ni-goethite). An increased amount of the low-crystalline or amorphous phase is in line with a higher background in the XRPD patterns (Figure 2). Two low intensity sextets, which can be attributed to Ni-ferrite, are present in the spectra of samples Ni20, Ni33 and Ni50, in line with the XRD results.

The ${ }^{57} \mathrm{Fe}$ Mössbauer spectra of calcined samples are shown in Figure 8 (left). The calculated Mössbauer parameters and phase identification are given in Table 4. All the spectra contain a sextet with Mössbauer parameters characteristic of hematite as the major component. Spectra of the samples containing $20 \mathrm{~mol} \% \mathrm{Ni}$ or greater also contain a broad doublet of increasing area with increasing
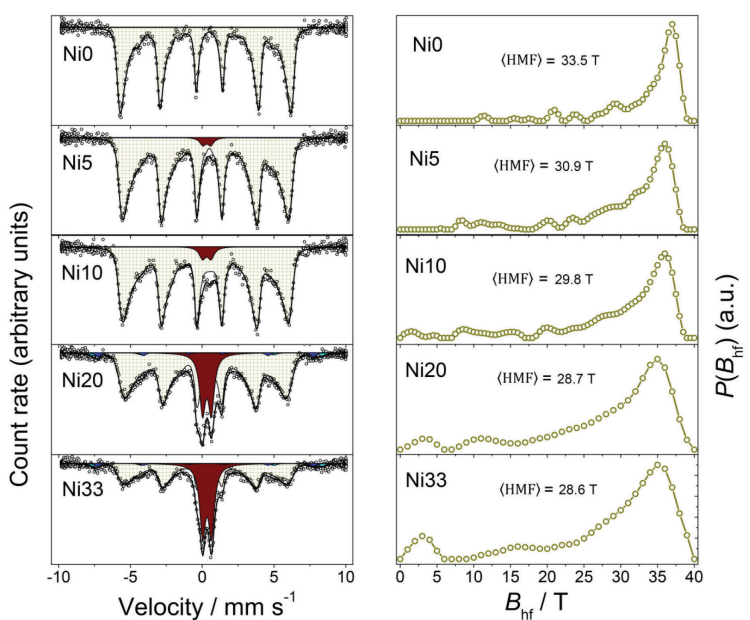

Figure 7. ${ }^{57} \mathrm{Fe}$ Mössbauer spectra of Ni-doped goethite samples recorded at $20{ }^{\circ} \mathrm{C}$ (left) and the corresponding hyperfine magnetic field distributions (right).
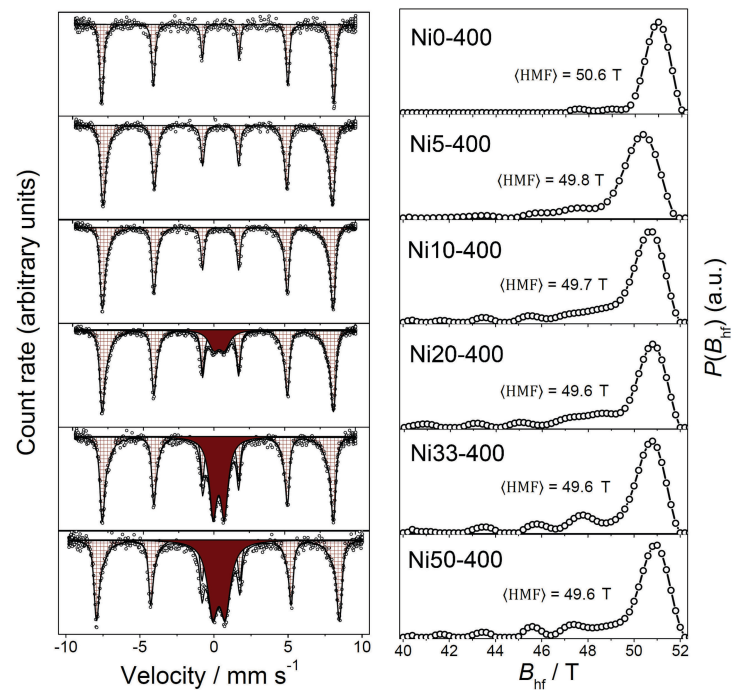

Figure $8 .{ }^{57} \mathrm{Fe}$ Mössbauer spectra of $\mathrm{Ni}$-doped hematite samples recorded at $20{ }^{\circ} \mathrm{C}$ (left) and the corresponding hyperfine magnetic field distributions (right).

$\mathrm{Ni}$ content. In line with XRPD patterns, this broad doublet can be tentatively attributed to the $\mathrm{Fe}^{3+}$ ions incorporated in $\mathrm{NiO}$ phase. Also, the presence of a superparamagnetic fraction cannot be excluded. Although XRPD patterns and magnetic measurements show the presence of small amounts of Ni ferrite in samples containing $10 \mathrm{~mol} \% \mathrm{Ni}$ or higher, the presence of two $\mathrm{Ni}$ ferrite sextets of low intensity in the Mössbauer spectra was neglected in the fitting procedure due to difficulties caused by their overlap with the hematite sextet. The spectra of hematite and Nidoped hematite were fitted by taking the hyperfine magnetic field (HMF) distribution into account. These HMF 
Table 4. ${ }^{57} \mathrm{Fe}$ Mössbauer parameters calculated by fitting of the Mössbauer spectra recorded at $20^{\circ} \mathrm{C}$ and phase identification

\begin{tabular}{|c|c|c|c|c|c|c|c|c|}
\hline Sample & $\begin{array}{c}\text { Spectral } \\
\text { component }\end{array}$ & $\delta / \mathrm{mm} \mathrm{s}^{-1}$ & $2 \varepsilon / \mathrm{mm} \mathrm{s}^{-1}$ & $\Delta / \mathrm{mm} \mathrm{s}^{-1}$ & $B_{h f}{ }^{(a)} / T$ & $\Gamma / \mathrm{mm} \mathrm{s}^{-1}$ & Area / \% & Phase \\
\hline $\mathrm{NiO}$ & sextet & 0.37 & -0.26 & & 33.5 & 0.25 & 100.0 & $\alpha-\mathrm{FeOOH}$ \\
\hline \multirow[t]{2}{*}{$\mathrm{Ni5}$} & sextet & 0.37 & -0.26 & & 30.9 & 0.28 & 97.8 & $\alpha-(\mathrm{Fe}, \mathrm{Ni}) \mathrm{OOH}$ \\
\hline & doublet & 0.32 & & 0.55 & & 0.50 & 2.2 & $\mathrm{Fe}(I I I)$ phase \\
\hline \multirow[t]{2}{*}{ Ni10 } & sextet & 0.37 & -0.26 & & 29.8 & 0.29 & 96.4 & $\alpha-(\mathrm{Fe}, \mathrm{Ni}) \mathrm{OOH}$ \\
\hline & doublet & 0.32 & & 0.59 & & 0.55 & 3.6 & $\mathrm{Fe}(I I I)$ phase \\
\hline \multirow[t]{4}{*}{$\mathrm{Ni} 20$} & sextet & 0.37 & -0.26 & & 28.7 & 0.30 & 77.6 & $\alpha-(\mathrm{Fe}, \mathrm{Ni}) \mathrm{OOH}$ \\
\hline & doublet & 0.33 & & 0.61 & & 0.50 & 17.8 & $\mathrm{Fe}(I I I)$ phase \\
\hline & sextet & 0.37 & & & 49.5 & 0.60 & 2.3 & $\mathrm{NiFe}_{2} \mathrm{O}_{4}$ (oct.) \\
\hline & sextet & 0.25 & & & 46.6 & 0.50 & 2.3 & $\mathrm{NiFe}_{2} \mathrm{O}_{4}$ (tet.) \\
\hline \multirow[t]{4}{*}{$\mathrm{Ni33}$} & sextet & 0.37 & -0.27 & - & 28.6 & 0.28 & 59.1 & $\alpha-(\mathrm{Fe}, \mathrm{Ni}) \mathrm{OOH}$ \\
\hline & doublet & 0.34 & & 0.61 & - & 0.49 & 34.9 & $\mathrm{Fe}(I I I)$ phase \\
\hline & sextet & 0.37 & & & 49.5 & 0.60 & 3.1 & $\mathrm{NiFe}_{2} \mathrm{O}_{4}$ (oct.) \\
\hline & sextet & 0.25 & & & 46.6 & 0.50 & 2.9 & $\mathrm{NiFe}_{2} \mathrm{O}_{4}$ (tet.) \\
\hline \multirow[t]{4}{*}{$\mathrm{Ni50}$} & sextet & 0.37 & -0.27 & & 27.5 & 0.31 & 53.8 & $\alpha-(\mathrm{Fe}, \mathrm{Ni}) \mathrm{OOH}$ \\
\hline & doublet & 0.34 & & 0.59 & & 0.52 & 35.8 & $\mathrm{Fe}(\mathrm{III})$ phase \\
\hline & sextet & 0.37 & & & 49.5 & 0.56 & 5.2 & $\mathrm{NiFe}_{2} \mathrm{O}_{4}$ (oct.) \\
\hline & sextet & 0.25 & & & 46.6 & 0.40 & 5.2 & $\mathrm{NiFe}_{2} \mathrm{O}_{4}$ (tet.) \\
\hline $\mathrm{NiO}-400$ & sextet & 0.37 & -0.20 & & 50.6 & 0.22 & 100.0 & $\alpha-\mathrm{Fe}_{2} \mathrm{O}_{3}$ \\
\hline $\mathrm{Ni5}-400$ & sextet & 0.37 & -0.19 & & 49.8 & 0.28 & 100.0 & $\alpha-(\mathrm{Fe}, \mathrm{Ni})_{2} \mathrm{O}_{3}$ \\
\hline Ni10-400 & sextet & 0.37 & -0.19 & & 49.7 & 0.27 & 100.0 & $\alpha-(\mathrm{Fe}, \mathrm{Ni})_{2} \mathrm{O}_{3}$ \\
\hline \multirow[t]{2}{*}{$\mathrm{Ni20}-400$} & sextet & 0.37 & -0.19 & & 49.6 & 0.29 & 84.0 & $\alpha-(\mathrm{Fe}, \mathrm{Ni})_{2} \mathrm{O}_{3}$ \\
\hline & doublet & 0.36 & & 0.76 & & 0.89 & 16.0 & $\mathrm{Fe}(\mathrm{III})$ phase \\
\hline \multirow[t]{2}{*}{ Ni33-400 } & sextet & 0.37 & -0.19 & & 49.6 & 0.28 & 63.0 & $\alpha-(\mathrm{Fe}, \mathrm{Ni})_{2} \mathrm{O}_{3}$ \\
\hline & doublet & 0.34 & & 0.79 & & 0.65 & 37.0 & $\mathrm{Fe}(\mathrm{III})$ phase \\
\hline \multirow[t]{2}{*}{ Ni50-400 } & sextet & 0.37 & -0.19 & & 49.6 & 0.28 & 57.6 & $\alpha-(\mathrm{Fe}, \mathrm{Ni})_{2} \mathrm{O}_{3}$ \\
\hline & doublet & 0.34 & & 0.85 & & 0.85 & 42.4 & $\mathrm{Fe}(\mathrm{III})$ phase \\
\hline
\end{tabular}

Errors: $\delta= \pm 0.01 \mathrm{~mm} \mathrm{~s}^{-1}, 2 \varepsilon= \pm 0.01 \mathrm{~mm} \mathrm{~s}^{-1}, \Delta= \pm 0.01 \mathrm{~mm} \mathrm{~s}^{-1}, B_{\mathrm{hf}}= \pm 0.2 \mathrm{~T}$.

Isomer shift is given relative to $\alpha$-Fe.

(a) $B_{\mathrm{hf}}$ is an average value of the hyperfine magnetic field distribution

distributions and their average values are given in Figure 8 (right). Ni doping caused a shift of HMF distributions to lower values because of the reduction of HMF at some Fe nuclei, due to the Ni-for-Fe substitution in their vicinity. Generally, Mössbauer spectroscopy is a powerful technique for the characterization of iron species taking part in different catalysis processes. ${ }^{[68]}$ Chen et al. ${ }^{[69]}$ used Mössbauer spectroscopy to detect the presence of $\mathrm{Fe}^{4+}$ species in a Ni-Fe hydroxide catalyst during steady-state water oxidation. In the case of the Fe hydroxide catalyst, $\mathrm{Fe}^{4+}$ species were not detected using Mössbauer spectroscopy and the same conditions, thus indicating the important role of $\mathrm{Ni}$ in the formation of $\mathrm{Fe}^{4+}$ species.
FT-IR spectra of undoped goethite and $\mathrm{Ni}$-doped goethite samples are shown in Figure 9. Goethite infrared absorption bands were assigned according to Verdonck et al. ${ }^{[70]}$ The $\mathrm{O}-\mathrm{H}$ stretching band shifted from $3126 \mathrm{~cm}^{-1}$ in undoped goethite to $3144 \mathrm{~cm}^{-1}$ in the spectrum of goethite containing $5 \mathrm{~mol} \% \mathrm{Ni}$, and to $3156 \mathrm{~cm}^{-1}$ in the spectrum of goethite containing $10 \mathrm{~mol} \% \mathrm{Ni}$. The Fe-O-H in-plane bending band $(\delta \mathrm{OH})$ at $889 \mathrm{~cm}^{-1}$ was shifted to $887 \mathrm{~cm}^{-1}$, while the out-of-plane bending band $(\mathrm{\gamma OH})$ at $794 \mathrm{~cm}^{-1}$ was shifted to $791 \mathrm{~cm}^{-1}$ in the $5 \mathrm{~mol} \% \mathrm{Ni}$ doped goethite. In the spectra of samples with a higher Ni content, these bands were slightly shifted to higher wave numbers. The positions of bending bands are dependent on both sample 


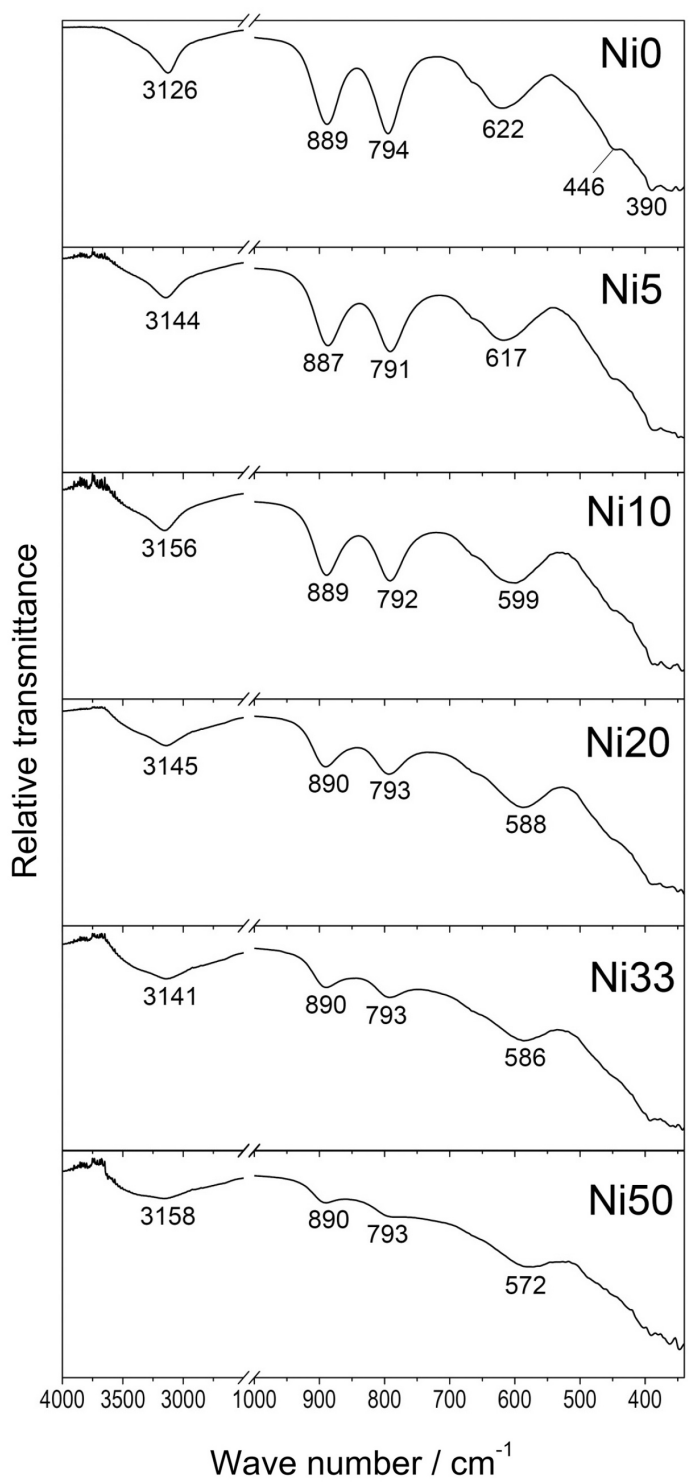

Figure 9. FT-IR spectra of Ni-doped goethite samples.

crystallinity ${ }^{[71,72]}$ and M-for-Fe substitution. ${ }^{[62-64,73,74]}$ In the present case, Ni-for-Fe substitution caused a shift to lower wave numbers, while an increase in $\mathrm{Ni}$-goethite particle size caused a shift to higher wave numbers. Fe-O stretching or the lattice vibration band at $622 \mathrm{~cm}^{-1}$ gradually shifted to lower wave numbers due to both $\mathrm{Ni}$-for-Fe substitution and increased particle size and crystallinity. A shift of this band to lower wave numbers has been observed in the spectra of goethite samples with larger crystallites and thicker particles ${ }^{[71,72]}$ and in goethites doped with metal cations heavier than iron cations $\left(\mathrm{Cu}^{2+}, \mathrm{Zn}^{2+}, \mathrm{Cd}^{2+}, \mathrm{Ir}^{3+}\right) \cdot{ }^{[62,63,73,74]}$

FT-IR spectra of undoped hematite and $\mathrm{Ni}$-doped hematite samples are shown in Figure 10. All bands in the spectrum of sample $\mathrm{NiO}$ could be assigned to hematite according to Serna et al. ${ }^{[75]} \mathrm{A}$ shoulder at $640 \mathrm{~cm}^{-1}$ and a

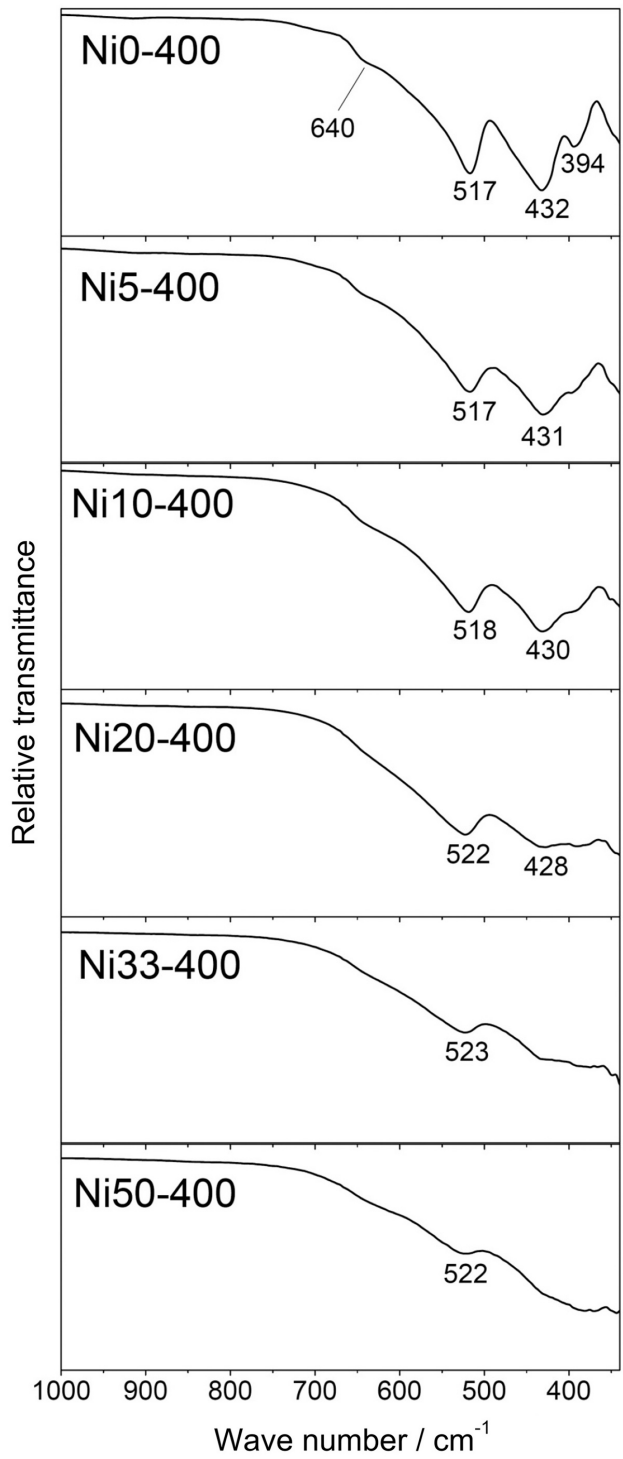

Figure 10. FT-IR spectra of Ni-doped hematite samples.

weak band at $394 \mathrm{~cm}^{-1}$ correspond to the $\mathrm{A} 2 \mathrm{u}$ vibration modes with a transition moment parallel to the $c$ axis, whereas the strongest bands at 517 and $432 \mathrm{~cm}^{-1}$ correspond to the Eu vibration modes with a transition moment perpendicular to the $c$ axis. Ni doping caused a slight shift in the position and a significant broadening and weakening of these IR bands. It has been shown that the position and intensity of hematite infrared bands are strongly dependent on particle size and shape. ${ }^{[37,75]}$

The UV-Vis-NIR spectra of goethite and Ni-doped goethite samples are shown in Figure 11 and the UV-VisNIR spectra of calcined samples are shown in Figure 12. Absorption bands in the visible $(400-700 \mathrm{~nm}$ ) and NIR (> $700 \mathrm{~nm}$ ) part of spectrum correspond to $\mathrm{Fe}^{3+}$ ligand field electron states transitions, while bands below $300 \mathrm{~cm}^{-1}$ 


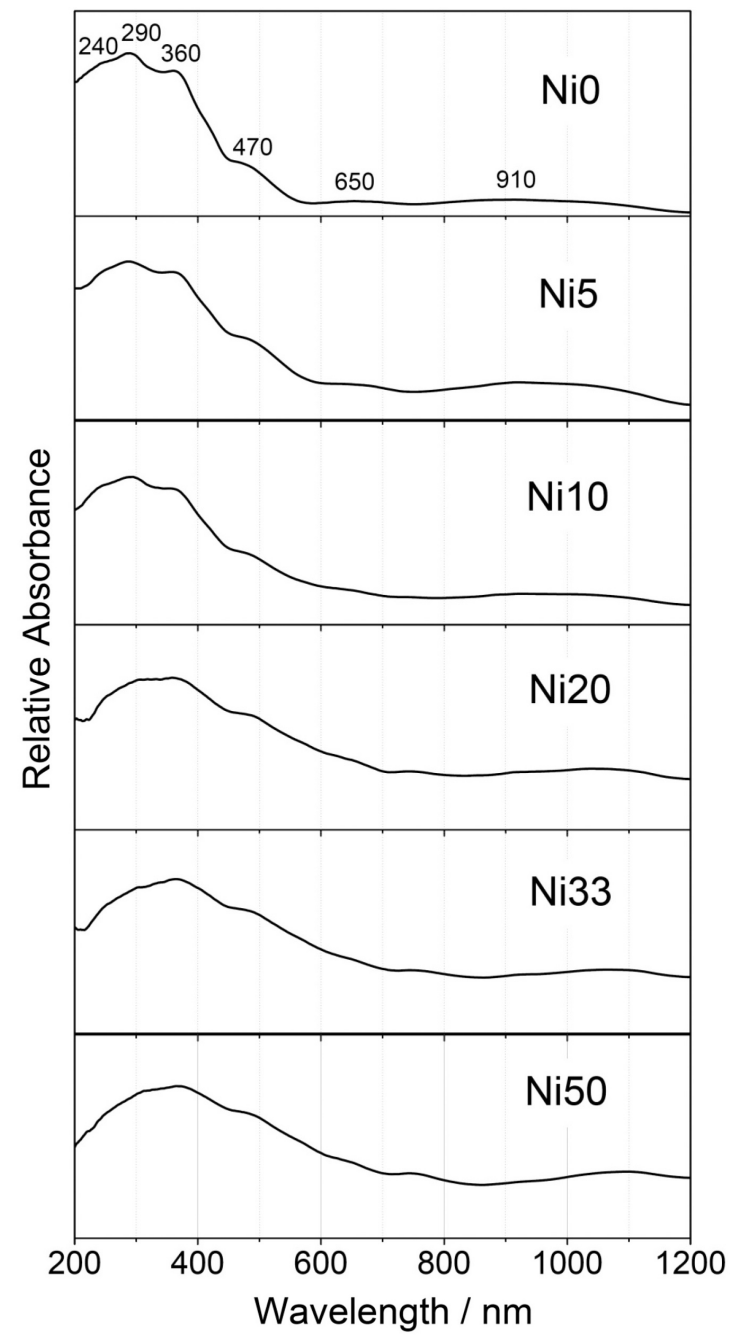

Figure 11. UV-Vis-NIR spectra of Ni-doped goethite samples.

correspond to the ligand-to-metal $\left(\mathrm{O}^{2-}\right.$ to $\left.\mathrm{Fe}^{3+}\right)$ chargetransfer transition. ${ }^{[76]}$ Figures 11 and 12 showed increased absorption in the visible and near IR region with increasing $\mathrm{Ni}$ content in the UV-Vis-NIR spectra of prepared samples from both series (non-calcined and calcined). This observation is in line with previous reports of increased absorption at longer wave lengths and reduced band gap in hematite by Ni doping. ${ }^{[43,44,46]}$

Selected samples were electrochemically evaluated and their oxygen evolution reaction (OER) polarization curves are shown in Figure 13. OER activities in terms of overpotential at $10 \mathrm{~mA} \mathrm{~cm}{ }^{-2}$ are given in brackets. Increased $\mathrm{Ni}$ content caused an increase in OER activity (a decrease in OER overpotential) of both non-calcined (Figure 13a) and calcined samples (Figure 13b). These observations are in line with recent studies that reported an increase in OER activity of $\mathrm{Ni}$-doped $\mathrm{FeOOH}$ with increased Ni content. ${ }^{[77,78]} \mathrm{A}$ number of studies also showed

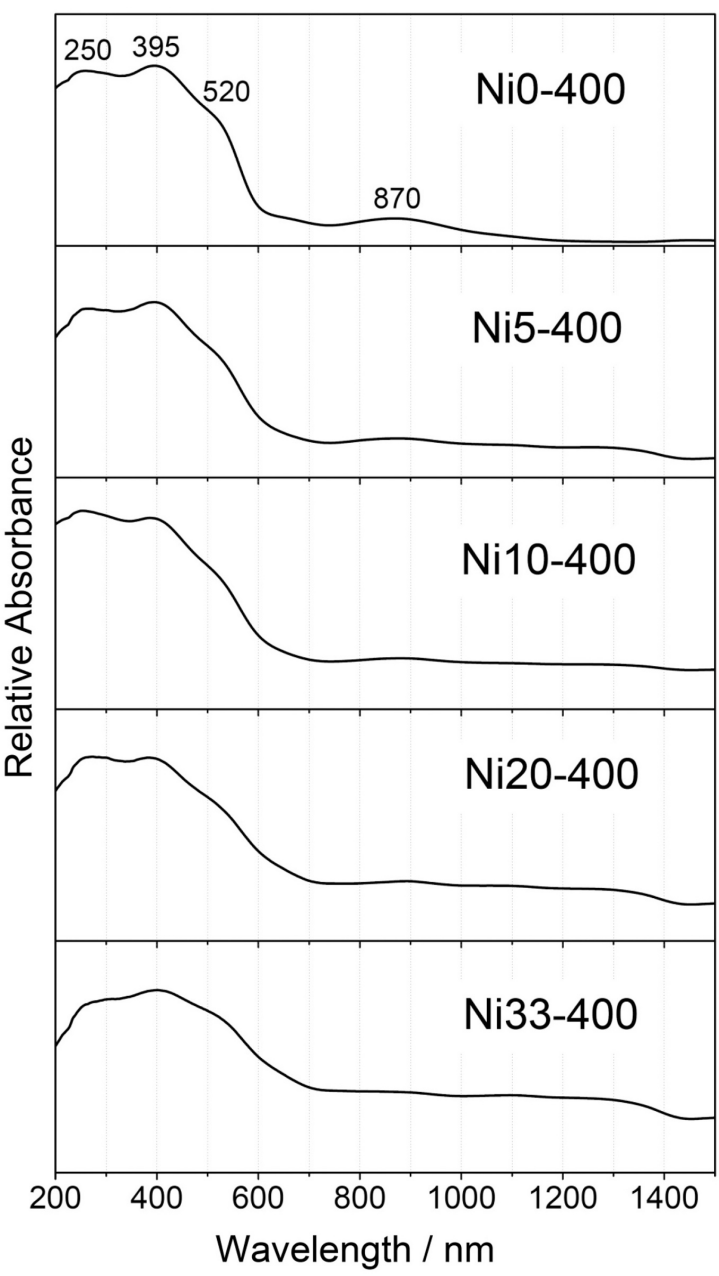

Figure 12. UV-Vis-NIR spectra of Ni-doped hematite samples.

that mixed $\mathrm{Ni}-\mathrm{Fe}$ hydroxides, oxyhydroxides and oxides have higher OER activity compared to pure $\mathrm{Ni}$ or $\mathrm{Fe}$ phases, ${ }^{[66,79-81]}$ indicating the synergistic action of $\mathrm{Fe}$ and $\mathrm{Ni}$ in these catalysts.

\section{CONCLUSIONS}

$\mathrm{Ni}$-doped goethite nanorods of good uniformity were synthesized by hydrothermal precipitation in the presence of tetramethylammonium hydroxide. Ni-doped hematite nanorods, obtained by calcination of $\mathrm{Ni}$-doped goethite nanorods, preserved the shape of precursor particles. It was shown that incorporation of $\mathrm{Ni}$ in goethite increases with initial $\mathrm{Ni}$ content; however, this process was accompanied with increasing amount of $\mathrm{Ni}$ ferrite formed by transformation of mixed Fe-Ni hydroxide (Ni-ferrihydrite). The maximum $\mathrm{Ni}$ doping in goethite could be obtained by the synthesis at higher $\mathrm{Ni}$ amounts and low 

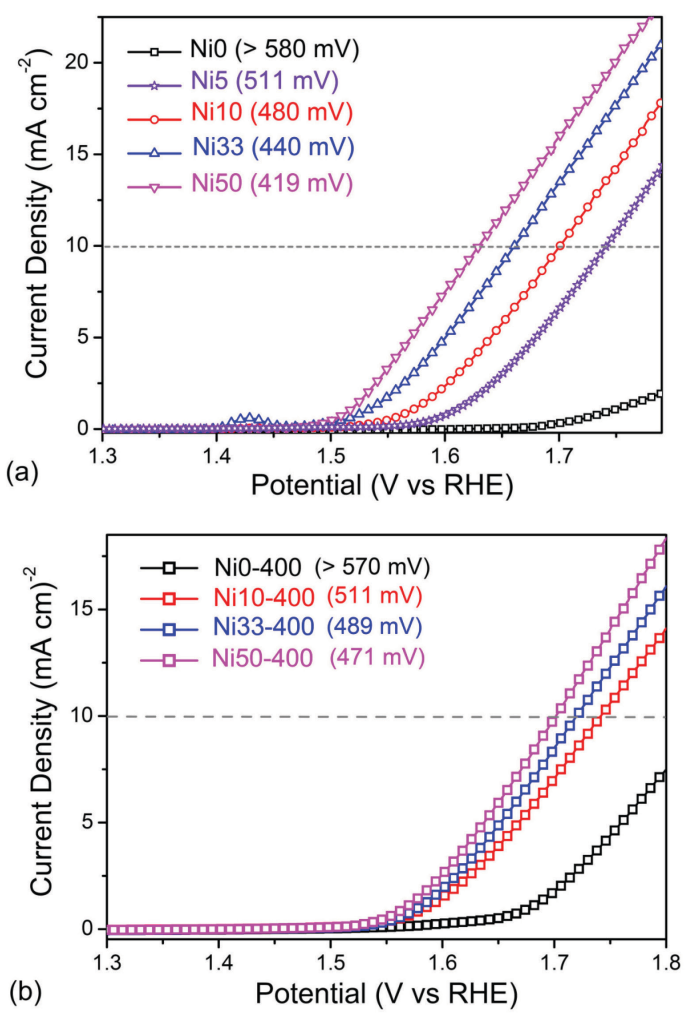

Figure 13. Linear sweep voltammograms (LSV) of selected $\mathrm{Ni}$-doped goethite (a) and $\mathrm{Ni}$-doped hematite (b) samples in $\mathrm{O}_{2}$-saturated $0.1 \mathrm{M} \mathrm{NaOH}$ electrolyte without IR correction. The electrode rotation rate is $1600 \mathrm{rpm}$. OER activities in terms of overpotential at $10 \mathrm{~mA} \mathrm{~cm}^{-2}$ are given in brackets.

temperatures where the transformation rate of $\mathrm{Ni}$-goethite and/or Ni-ferrihydrite to Ni ferrite is lower. Removing of the untransformed Ni-ferrihydrite by leaching is needed to obtain a pure Ni-goethite phase. Ni-doped hematite contained an increase of structural defects with increase of $\mathrm{Ni}$-substitution. Ni-doped goethite and hematite samples, synthesized in the present work, showed improved OER catalytic activity compared to pure phases. These samples have the potential for possible application like catalysts, photocatalysts, gas sensors, or similar.

Acknowledgments. This research was supported by the Croatian Science Foundation (project number IP-2016-068254), SAFU (project KK.01.1.1.01.0001), the Strategic Priority Research Program of the Chinese Academy of Sciences (Grant No. XDA09030104) and the Natural Science Foundation of China (21576258, 21476232), bilateral Croatian-Chinese scientific project "Iron oxide nanostructures for environmental and energy applications" and bilateral Croatian-Serbian scientific project "Nanostructured iron oxides for environmental applications".

\section{REFERENCES}

[1] R. M. Cornell, U. Schwertmann, The Iron Oxides, Structure, Properties, Reactions, Occurrence and Uses, second ed., Wiley-VCH, Weinheim, 2003.

[2] K. Sivula, F. Le Formal, M. Grätzel, ChemSusChem 2011, 4, 432.

[3] J. Ma, J. Teo, L. Mei, Z. Zhong, Q. Li, T. Wang, X. Duan, J. Lian, W. Zheng, J. Mater. Chem. 2012, 22, 11694.

[4] B. Wang, J.S. Chen, X.W.D. Lou, J. Mater. Chem. 2012, 22, 9466.

[5] M. Müller, J. C. Villalba, F. Q. Mariani, M. Dalpasquale, M. Zvolinski Lemos, M. F. Gonzalez Huila, F.J. Anaissi, Dyes Pigments 2015, 120, 271.

[6] P. Oulego, M. A. Villa-García, A. Laca, M. Diaz, Dalton Trans. 2016, 45, 9446.

[7] C. Zhang, Y. Li, T.-J. Wang, Y. Jiang, J. Fok, Appl. Surf. Sci. 2017, 425, 272.

[8] X. Zhou, H. Yang, C. Wang, X. Mao, Y. Wang, Y. Yang, G. Liu, J. Phys. Chem. C 2010, 114, 17051.

[9] X. Zhou, J. Lan, G. Liu, K. Deng, Y. Yang, G. Nie, J. Yu, L. Zhi, Angew. Chem. Int. Ed. 2012, 51, 178.

[10] Y. Xu, G. Zhang, G. Du, Y. Sun, D. Gao, Mater. Lett. 2013, 92, 321.

[11] J. Liu, Z. Wu, Q. Tian, W. Wu, X. Xiao, CrystEngComm 2016, 18, 6303.

[12] J. Frydrych, L. Machala, J. Tucek, K. Siskova, J. Filip, J. Pechousek, K. Safarova, M. Vondracek, J. H. Seo, O. Schneeweiss, M. Grätzel, K. Sivula, R. Zboril, J. Mater. Chem. 2012, 22, 23232.

[13] Y. Zhai, X. Ma, H. Mao, W. Shao, L. Xu, Y. He, Y. Qian, Adv. Electron. Mater. 2015, 1400057.

[14] J. Xu, Y. Li, B. Yuan, C. Shen, M. Fu, H. Cui, W. Sun, Chem. Eng. J. 2016, 291, 174.

[15] H. Liu, T. Peng, H. Sun, R. Xie, G. Ma, RSC Adv. 2017, 7, 11414.

[16] C. R. M. Butt, D. Cluzel, Elements 2013, 9, 123.

[17] G. Dublet, F. Juillot, G. Morin, E. Fritsch, D. Fandeur, G. E. Brown Jr., Geochim. Cosmochim. Acta 2015, 160, 1.

[18] M. L. Carvalho-E-Silva, A. Y. Ramos, H. C. N. Tolentino, J. Enzweiler, S. M. Netto, M. D. C. M. Alves, Am. Mineral. 2003, 88, 876.

[19] M. L. M. De Carvalho-E-Silva, C. S. M. Partiti, J. Enzweiler, S. Petit, S. M. Netto, S. M. B. De Oliveira, Hyperfine Interact. 2002, 142, 559.

[20] J. Gerth, Geochim. Cosmochim. Acta 1990, 54, 363.

[21] T. Ishikawa, A. Nagashima, K. Kandori, J. Mater. Sci. 1991, 26, 6231.

[22] R. M. Cornell, W. Schneider, R. Giovanoli, J. Chem. Technol. Biot. 1992, 53, 73.

[23] S. Krehula, S. Musić, S. Popović, J. Alloys Compd. 2005, 403, 368. 
[24] M. A. Wells, R. W. Fitzpatrick, R. J. Gilkes, Clays Clay Miner. 2006, 54, 176.

[25] R. D. Shannon, Acta Cryst. A 1976, 32, 751.

[26] M. Mohapatra, S.K. Sahoo, S. Anand, R.P. Das, J. Colloid Interface Sci. 2006, 298, 6.

[27] S. Mustafa, S. Khan, M.I. Zaman, Water Res. 2010, 44, 918.

[28] W. F. de Souza, I. R. Guimarães, L. C. A. Oliveira, A. S. Giroto, M. C. Guerreiro, C. L. T. Silva, Appl. Catal. A 2010, 381, 36.

[29] J. M. D. Coey, G. A. Sawatzky, J. Phys. C: Solid St. Phys. 1971, 4, 2386.

[30] I. Ayub, F. J. Berry, R. L. Bilsborrow, Ö. Helgason, R. C. Mercader, E. A. Moore, S. J. Stewart, P. G. Wynn, J. Solid State Chem. 2001, 156, 408.

[31] F. J. Berry, C. Greaves, J. McManus, M. Mortimer, G. Oates, J. Solid State Chem. 1997, 130, 272.

[32] F. J. Berry, A. Bohorquez, C. Greaves, J. McManus, E. A. Moore, M. Mortimer, J. Solid State Chem. 1998, 140, 428.

[33] F. J. Berry, A. Bohorquez, E. A. Moore, Solid State Commun. 1999, 109, 207.

[34] F. J. Berry, C. Greaves, Ö. Helgason, J. McManus, H. M. Palmer, R. T. Williams, J. Solid State Chem. 2000, 151, 157.

[35] J. M. G. Amores, V. S. Escribano, G. Busca, E. F. Lopez, M. Saidi, J. Mater. Chem. 2001, 11, 3234.

[36] T. Grygar, P. Bezdička, J. Dědeček, E. Petrovský, O. Schneeweiss, Ceramics-Silikáty 2003, 47, 32.

[37] S. Krehula, G. Štefanić, K. Zadro. L. Kratofil Krehula, S. Musić, J. Alloys Compd. 2012, 545, 200.

[38] S. Krehula, M. Ristić, S. Kubuki, Y. lida, M. Perović, M. Fabián, S. Musić, J. Alloys Compd. 2015, 634, 130.

[39] S. Krehula, M. Ristić, M. Reissner, S. Kubuki, S. Musić, J. Alloys Compd. 2017, 695, 1900.

[40] B. Singh, D. M. Sherman, R. J. Gilkes, M. Wells, J. F. W. Mosselmans, Clays Clay Miner. 2000, 48, 521.

[41] M. A. Wells, R. W. Fitzpatrick, R. J. Gilkes, J. Dobson, Geophys. J. Int. 1999, 138, 571.

[42] C. Saragovi, J. Arpe, E. Sileo, R. Zysler, L. C. Sanchez, C. A. Barrero, Phys. Chem. Miner. 2004, 31, 625.

[43] Y. Liu, Y.-X. Yu, W.-D. Zhang, Electrochim. Acta 2012, 59, 121.

[44] G. Iervolino, I. Tantis, L. Sygellou, V. Vaiano, D. Sannino, P. Lianos, Appl. Surf. Sci. 2017, 400, 176.

[45] P. Zhao, B.E. Koel, ACS Appl. Mater. Interfaces 2014, 6, 22289.

[46] J. Kocher, A. Kumar, A. Kumar, S. Priya, J. Kumar, Phys. Status Solidi B 2014, 251, 1552.

[47] O. M. Lemine, I. Ghiloufi, M. Bououdina, L. Khezami, M. O. M'hamed, A.T. Hassan, J. Alloys Compd. 2014, 588, 592.

[48] R. Satheesh, K. Vignesh, A. Suganthi, M. Rajarajan, J. Environ. Chem. Eng. 2014, 2, 1956.
[49] E. J. de Melo, J.P. de Mesquita, M. C. Pereira, L. C. D. Cavalcante, E. dos Santos Filho, J. D. Fabris, J. D. Ardisson, L. C. Alves de Oliveira, Hyperfine Interact. 2017, 238, 59.

[50] A. Lassoued, M. S. Lassoued, S. García-Granda, B. Dkhil, S. Ammar, A. Gadri, J. Mater. Sci. Mater. El. 2018, 29, 5726.

[51] S. Sivakumar, D. Anusuya, C.P. Khatiwada, J. Sivasubramanian, A. Venkatesan, P. Soundhirarajan, Spectrochim. Acta A 2014, 128, 69.

[52] D. Wang, M. Zhang, J. Yuan, Y. Lin, C. Song, Mater. Lett. 2015, 157, 147.

[53] W. Cheng, J. He, Z. Sun, Y. Peng, T. Yao, Q. Liu, Y. Jiang, F. Hu, Z. Xie, B. He, S. Wei, J. Phys. Chem. C 2012, 116, 24060.

[54] R. Suresh, K. Giribabu, R. Manigandan, A. Stephen, V. Narayanan, RSC Adv. 2014, 4, 17146.

[55] S. Krehula, S. Popović, S. Musić, Mater. Lett. 2002, 54, 108 .

[56] D. M. E. Thies-Weesie, J. P. de Hoog, M. H. Hernandez Mendiola, A. V. Petukhov, G. J. Vroege, Chem. Mater. 2007, 19, 5538.

[57] L. Lutterotti, Nucl. Instrum. Methods. Phys Res B. 2010, 268, 334.

[58] Z. Klencsar, E. Kuzmann, A. Vertes, J. Radioanal, Nucl. Chem. 1996, 201, 105.

[59] S. Chkoundali, S. Ammar, N Jouini, F. Fiévet, P. Molinié, M. Danot, F. Villain, J.-M. Grenèche, J. Phys. Condens. Matter 2004, 16, 4357.

[60] B. Singh, D. M. Sherman, J. F. W. Mosselmans, R. J. Gilkes, M. A. Wells, Clay Miner. 2002, 37, 639.

[61] R. M. Cornell, R. Giovanoli, Clays Clay Miner. 1987, 35, 11.

[62] S. Krehula, S. Musić, Ž. Skoko, S. Popović, J. Alloys Compd. 2006, 420, 260.

[63] S. Krehula, S. Musić, J. Alloys Compd. 2012, 516, 207.

[64] S. Krehula, M. Ristić, S. Kubuki, Y. lida, L. Kratofil Krehula, S. Musić, J. Alloys Compd. 2016, 658, 41.

[65] L. Löffler, W. Mader, J. Eur. Ceram. Soc. 2006, 26, 131.

[66] M. Landers, R. J. Gilkes, M. A. Wells, Clays Clay Miner. 2009, 57, 751.

[67] E. Wolska, U. Schwertmann Z. Kristallog. 1989, 189, 233.

[68] X. Li, K. Zhu, J. Pang, M. Tian, J. Liu, A.I. Rykov, M. Zheng, X. Wang, X. Zhu, Y. Huang, B. Liu, J. Wang, W. Yang, T. Zhang, Appl. Catal. B 2018, 224, 518.

[69] J. Y. C. Chen, L. Dang, H. Liang, W. Bi, J.B. Gerken, S. Jin, E. E. Alp, S. S. Stahl, J. Am. Chem. Soc. 2015, 137, 15090.

[70] L. Verdonck, S. Hoste, F. F. Roelandt, G. P. Van Der Kelen, J. Mol. Struct. 1982, 79, 273.

[71] U. Schwertmann, P. Cambier, E. Murad, Clays Clay Miner. 1985, 33, 369. 
[72] S. Krehula, S. Musić, J. Cryst. Growth 2008, 310, 513.

[73] S. Krehula, S. Musić, J. Alloys Compd. 2007, 431, 56.

[74] S. Krehula, S. Musić, J. Mol. Struct. 2007, 834-836, 154.

[75] C. J. Serna, J. L. Rendon, J. E. Iglesias, Spectrochim. Acta A 1982, 38, 797.

[76] D. M. Sherman, T. D. Waite, Am. Mineral. 1985, 70, 1262.

[77] W. D. Chemelewski, J. R. Rosenstock, C. B. Mullins, J. Mater. Chem. A 2014, 2, 14957.
[78] D. Friebel, M. W. Louie, M. Bajdich, K. E. Sanwald, Y. Cai, A. M. Wise, M. J. Cheng, D. Sokaras, T. C. Weng, R. Alonso-Mori, R. C. Davis, J. R. Bargar, J. K. Nørskov, A. Nilsson, A. T. Bell, J. Am. Chem. Soc. 2015, 137, 1305.

[79] M. Gong, H. Dai, Nano Research 2015, 8, 23.

[80] K. Zhu, H. Liu, M. Li, X. Li, J. Wang, X. Zhu, W. Yang, J. Mater. Chem. A 2017, 5, 7753.

[81] S. Krehula, M. Ristić, C. Wu, X. Li, L. Jiang, J. Wang, G. Sun, T. Zhang, M. Perović, M. Bošković, B. Antić, L. Kratofil Krehula, B. Kobzi, S. Kubuki, S. Musić, J. Alloys Compd. 2018, 750, 687. 